City profile

\title{
City profile: Ankara
}

\author{
Bülent Batuman \\ Bilkent University, Department of Urban Design and Landscape Architecture, 06800 Ankara, Turkey
}

\section{A R T I C L E I N F O}

\section{Article history:}

Received 26 July 2011

Received in revised form 23 May 2012

Accepted 30 May 2012

Available online 26 June 2012

\section{Keywords:}

Ankara

Turkey

Squatters

Islamic neoliberalism

Urban politics

Urban regeneration

Ankara Greater Municipality

\begin{abstract}
A B S T R A C T
Although Ankara has a long history, it is generally known for its twentieth century development as the designed capital of the newly-born Turkish nation-state. The early episode of the city's growth displayed a typical example of modernization with the hand of a determined nationalist government. Yet, the second half of the century, also similar to other developing parts of the world, witnessed the uncontrollable expansion of the city with the emergence of squatter areas. Providing a brief discussion of this history, the article focuses on the recent developments in Ankara's urban growth, which was marked by an original trend in urban politics. A significant combination of neoliberal development strategies and Islamist social welfare policies has emerged in the Turkish cities in the last two decades. Ankara, being the symbol of republican modernization distinguished with a radical interpretation of secularism, suffers this political tension and witnesses the social predicaments of an immense transformation shaped by urban regeneration projects.
\end{abstract}

(c) 2012 Elsevier Ltd. All rights reserved.

\section{Introduction}

As the capital city, the history of Ankara in the 20th century is generally considered to parallel that of republican Turkey. It began as a declining Ottoman town, although republican historiography presents it as a city built from scratch. As the symbol of the young nation, Ankara was always imagined as a tabula rasa and its construction as a modern capital was presented as a concrete signifier of nation-building. Obviously, Ankara is not unique in terms of being designed as the capital of a newly established nation-state (Vale, 1992). Yet, this symbolic weight has affected government development strategies for the city. In this respect, perhaps the most curious aspect of Ankara today is its urban development in the last eighteen years under an Islamist local administration. While most Turkish cities are currently ruled in the same fashion, being the symbol of republican modernization marked by a radical interpretation of secularism, Ankara has suffered the burden of this political tension. Below, after a brief discussion of the city's growth throughout the first half of the 20th century, I will analyze the contemporary condition of Ankara, the last years of which are marked by an original combination of neoliberal development strategies and Islamist social welfare policies. The article is structured in two major sections: the first one providing an historical account until the 1950s, and the second analyzing the later period through a number of themes: planning, transportation, local administration and housing.

\section{History: Ankara in the early 20th century}

\section{Designing a new capital}

Before the First World War, Ankara was a small Ottoman town with a population less than 30,000 . In the aftermath, which ended with the collapse of the Ottoman Empire, the republicans arrived in Ankara to pursue a War of Independence. A major factor in the city's choice by the republicans was its location at the heart of the Anatolian peninsula (Fig. 1). Between 1920 and 1923, the city served as the center of the nationalist struggle and was later declared the capital city of the nation-state. By 1923 the city had already begun drawing migrants, which would then accelerate, especially with state officials coming from Istanbul. The shortage of adequate housing for the newcomers also brought about the need for labor in the construction sector as the population rose to 75,000 by 1927 . For the republican cadres who desired to create a modern society, the elite newcomers were expected to become a model for a modern life style. Within this vision, Ankara was desired to be a modernist capital, similar to its European counterparts. ${ }^{1}$

In 1924 , a plan was produced for the city by the German city planner Carl Christoph Lörcher. In March 1925, a district of four million square meters in the southern part of the city was expropriated and opened to settlement. Since this development was not considered in the making of the plan, Lörcher was asked to

\footnotetext{
${ }^{1}$ For the story of the planning and the construction of the capital, see Tankut (1994). 


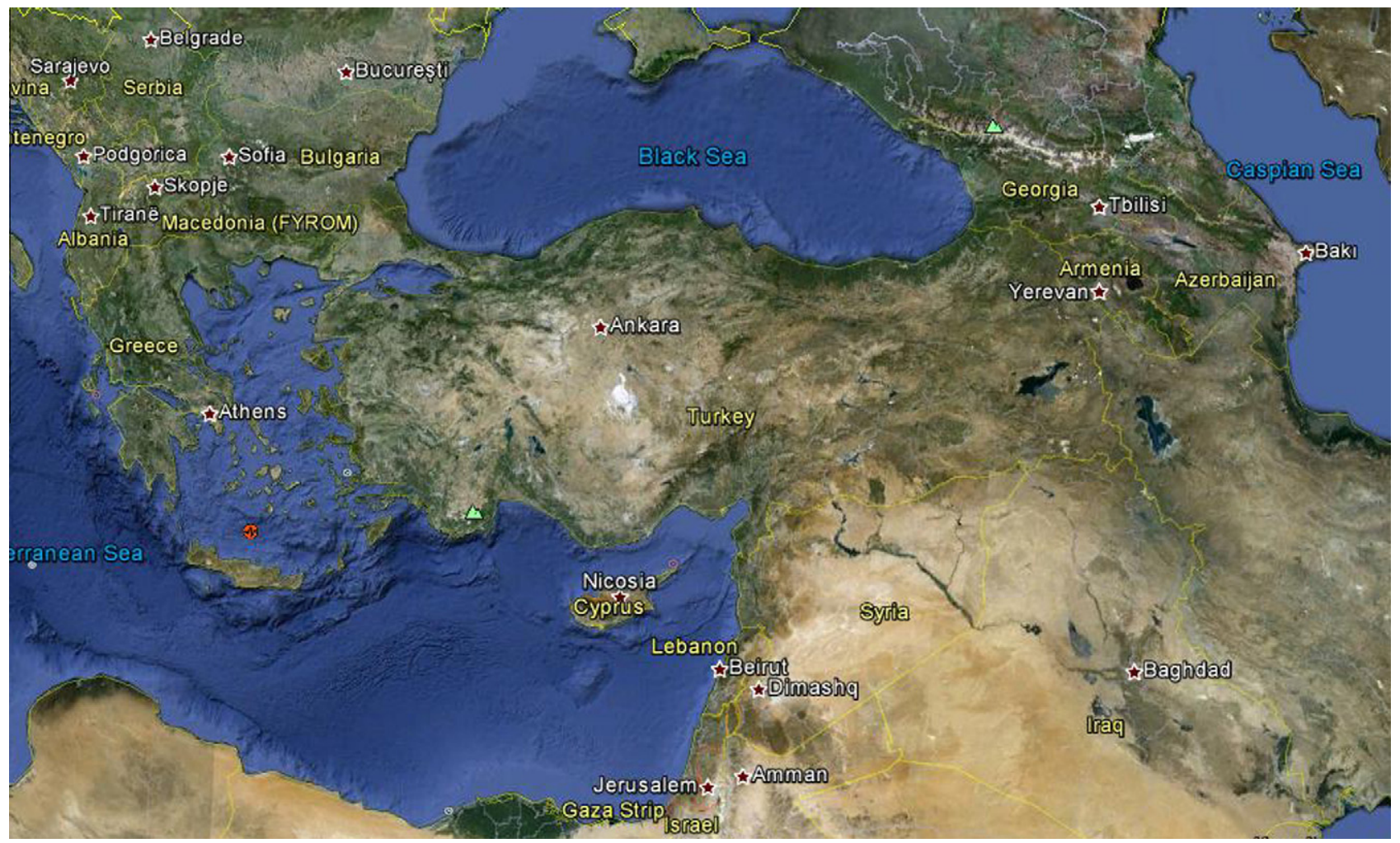

Fig. 1. The location of Ankara (source: Google Earth).

develop another plan for this "new city" -Yenişehir- which was to include government buildings and residences for state employees (Fig. 2). ${ }^{2}$ Following the expropriation, the physical and social environment in and around Yenişehir began to develop rapidly. While the old city continued to house the market activities for local people, Yenişehir sheltered élite residences and government activities. The railway, which had marked the city limits since its construction in 1893, provided a natural border between the old city and the new one.

The incoming migration and the rapid growth of the city soon brought about the need for a comprehensive plan. A committee was sent to Germany in 1927 to choose and invite prominent architects to participate in a competition. The winning project, that of the German planner Hermann Jansen was approved in 1929. In his design, Yenişehir was not proposed as the new center for Ankara. Instead, the old Citadel was to keep its central role, while Yenişehir was assigned as the site for a new style of life (Fig. 3). ${ }^{3}$

In the 1930s, both the economy and the social life in Ankara began to flourish. Luxurious hotels and restaurants increased in number, radio broadcasting was started, and bookstores and cinemas were opened for the first time. With its parks, boulevards and new buildings Yenişehir especially was a lively environment used by the élite inhabitants of the district, whose living conditions were immune even to the Second World War. The continuous migration to Ankara was also not affected by the War; the city's population increased from 157,000 in 1940 to 226,000 in 1945 (Table 1). The new international status quo, however, was to bring new dynamics into play and to shape Ankara as well as the whole country.

\footnotetext{
${ }^{2}$ For a detailed study of the Lörcher Plan, see Cengizkan (2004).

${ }^{3}$ For a social history of Ankara's development via the analysis of Yenişehir, see Batuman (2009a)
}

The capital of the capital

After 1945, the Turkish government started a process of structural adaptation regarding economic and political policies compatible with the Western world. Politically, the single-party rule of the Republican People's Party (RPP) that marked the early decades of republican history came to an end. In 1950, a new party - the Democrat Party - came to power and pursued further integration with the global market. In response to the liberalization of the economy, American funds flowed into Turkey within the frame of the Marshall Plan.

While the modernization of agriculture created surplus labor, a new road network also facilitated massive migration to the big cities. Within a decade (between 1950 and 1960) 1.5 million immigrants arrived into urban areas $(600,000$ into the four largest cities). The urban population, which was $16.4 \%$ in 1927 and had merely reached $18.5 \%$ in 1950 , jumped to $25.9 \%$ in 1960 (Keleş \& Danielson, 1985, p. 28). Neither job opportunities or the housing stock in major cities were sufficient to accommodate such migration. The result was the emergence of squatter houses -gecekondu(which in Turkish literally means "landed in one night") around the cities. The inadequacy of regular employment led to the rise of a "second economy," an informal sector which was characterized by small-scale service enterprises, labor-intensive employment, and substantial excess labor (Keleş \& Danielson, 1985, p. 41). The immigrants who started to work in such marginal jobs at the beginning of the 1950s created spaces in all sectors of the urban economy and became an organic part of urban life.

Since Ankara had experienced a constant level of migration since the early days of the Republic, it was the first to experience the gecekondu phenomenon (Senyapilı, 2004). In 1950, the population of Ankara reached 289,000 , which was already beyond the number projected for 1980 by the Jansen plan. By 1960, it would reach 650,000. Although Ankara functioned as the political and 


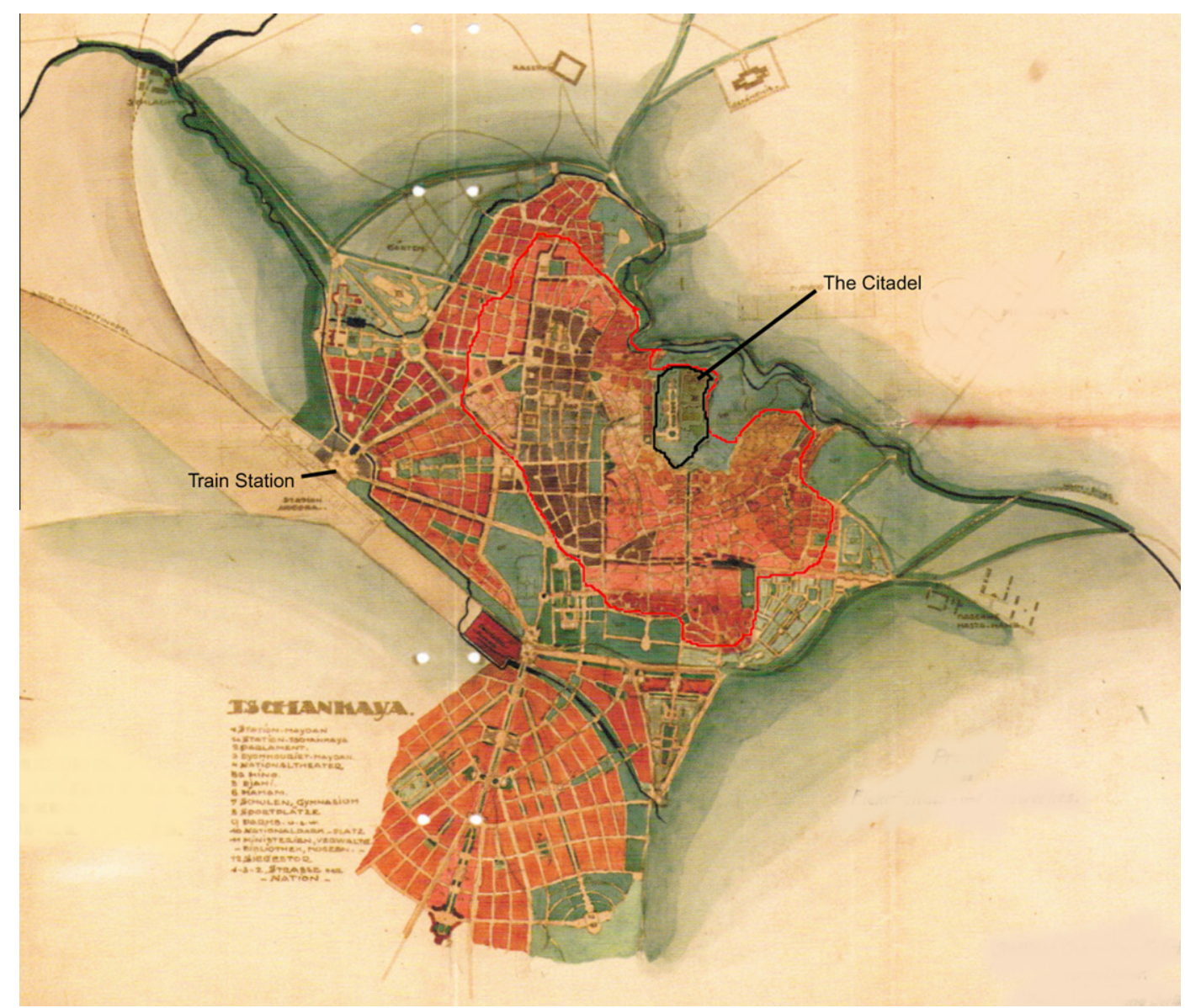

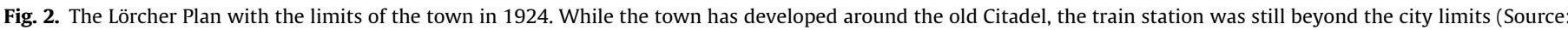

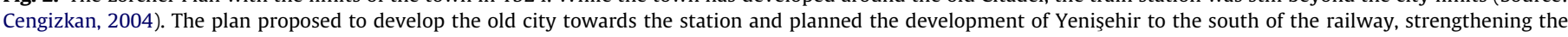

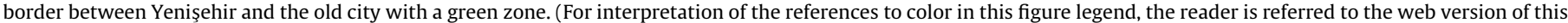
article.)

administrative center of the country, Istanbul remained as the country's industrial and business center, its primary port as well as the center of cultural and intellectual life. As Ankara was seen as the symbol of the early republican period, the Democrat Party administration promoted Istanbul rather than Ankara for urban development, and during the 1950s, public investments flowed into Istanbul. Ankara's identification with the early republican period would continue to mark the government attitude towards the city in the upcoming years.

Nevertheless, Ankara transformed significantly during the 1950s. In 1952, Kızılay, the central hub of Yenişehir, was formally accepted as the Central Business District. Landowners were permitted to build apartment blocks along the boulevard, with shopping arcades on the ground and basement floors. Consistent with the conventional "international" image of the CBD, the first skyscraper of Turkey was also built in Kızılay. Bank branches, upper class hotels and restaurants, advertising, real estate, foreign and domestic travel agencies and insurance offices were opened. On the upper floors of apartment buildings, luxury services such as fashion houses, photographers, and hairdressers replaced residences (Akçura, 1971, p. 123). This was the shift of the city core from the old center Ulus to Yenişehir.

By the second half of the 1950s, Ankara had become a large city with a population of half a million. In the following decades, the city would witness continuous expansion. While the major force behind urban growth was state-led industrialization until the 1980s, afterwards it assumed a new form of locally administered neoliberalization. I will analyze below the urban development of
Ankara after the 1950s, along four themes: planning, transportation, local administration and housing.

The order of these themes is consciously organized, since they also represent the priorities of urban growth strategies throughout the decades that will be discussed. In the 1960s and the 1970s, the major issues were the expansion and spatial organization of industrial capacities of the city in order to absorb the migrants arriving in Ankara. This also meant the guidance of the city's growth outside the geographical boundaries defining its core. The physical expansion of the city also brought in the issue of transportation. In the 1980s, local administrations were reorganized and granted new powers in terms of planning as well as budget size. This allowed them to gradually become the major actors in directing urban growth. Finally, housing was effectively utilized as a development strategy with the unprecedented amount of housing construction in the 2000s.

\section{Planning}

The uncontrollable growth of the city due to in-migration resulted in a second competition for the master plan for Ankara in 1955 by which time both the population rate and the physical boundaries of the city had expanded beyond the projections of the Jansen Plan. The winning proposal, which was based on a population projection of 750,000 for the year 2000 , would also fail to foresee and control urban growth. Yet it legalized and systematized a major growth strategy that would mark the development of not only Ankara but all major Turkish cities. Accordingly, city 


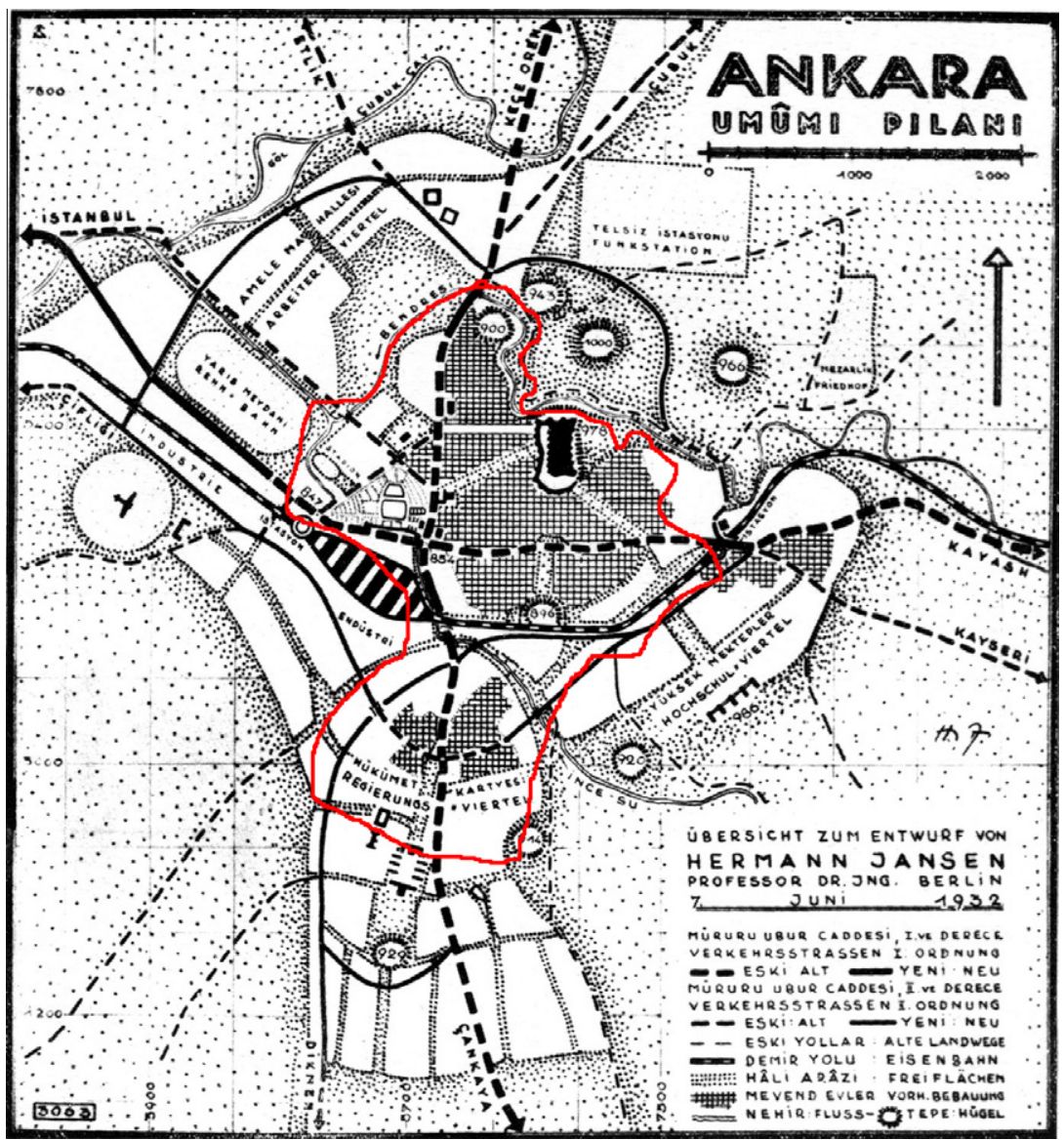

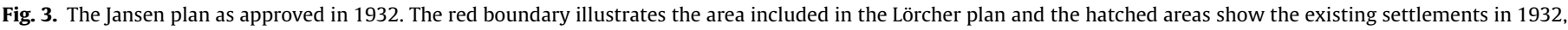

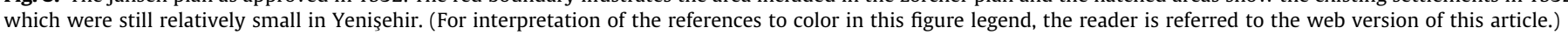

Table 1

Population of Ankara.

\begin{tabular}{lr}
\hline 1927 & 74,553 \\
1935 & 122,720 \\
1940 & 157,242 \\
1945 & 226,712 \\
1950 & 288,536 \\
1955 & 451,241 \\
1960 & 650,067 \\
1965 & 905,660 \\
1970 & $1,236,152$ \\
1975 & $1,606,040$ \\
1980 & $1,800,587$ \\
1985 & $2,228,398$ \\
1990 & $2,559,511$ \\
1997 & $2,917,602$ \\
2000 & $3,203,362$ \\
2007 & $3,763,591$ \\
2008 & $4,194,939$ \\
2009 & $4,306,105$ \\
2010 & $4,431,719$ \\
\hline
\end{tabular}

growth, it was decided, was to be pursued via the destruction of the existing urban fabric and the construction of high-rise blocks (Cengizkan, 2005, p. 41). This strategy was already a dominant tendency on the part of landowners, whom the local administrations chose not to resist but to exploit via the creation of clientelist relations. In this respect, the plan was in tune with both the expectations of the landowners and the city administration. From then on, Turkish cities, and especially the central zones of the major ones, would develop along with the periodic raising of building heights. The surplus rent created with these regulations was the major force driving urban development.

By the second half of the 1950s, the existing agricultural export model began to fail and was replaced with a new model of importsubstituting industrialization which would mark the next two decades. ${ }^{4}$ This strategy of development was one adopted by many of the nations that gained independence after 1945 (Roberts, 1989). The transformation towards planned industrialization required a new institutional framework, a major element of which was the establishment of a Ministry of Reconstruction and Resettlement, separate from the existing Ministry of Public Works, to direct physical planning activities in the country.

In 1965, autonomous planning bureaus that would work in coordination with the Ministry of Reconstruction and Resettlement were established for Istanbul, Ankara and Izmir. The major problems to be solved by the Ankara Master Plan Bureau were the spatial organization of industrial zones and directing the city's growth outwards, since the urban core was already saturated and the city had reached the limits of the geomorphologic basin in which it was located. It was proposed to develop the city to the west, the only direction where the city fringe was not surrounded with squatter areas (Fig. 4). Industrial and residential zones were proposed along this axis, and mass housing projects were developed within these zones. The plan, which targeted the year 1990, was officially approved only in 1982; yet it was influential in directing the city's peripheral development even during the 1970s since the Bureau's proposals were followed by the authorities. A green belt was

\footnotetext{
${ }^{4}$ For the details of this transformation, see Keyder (1987).
} 


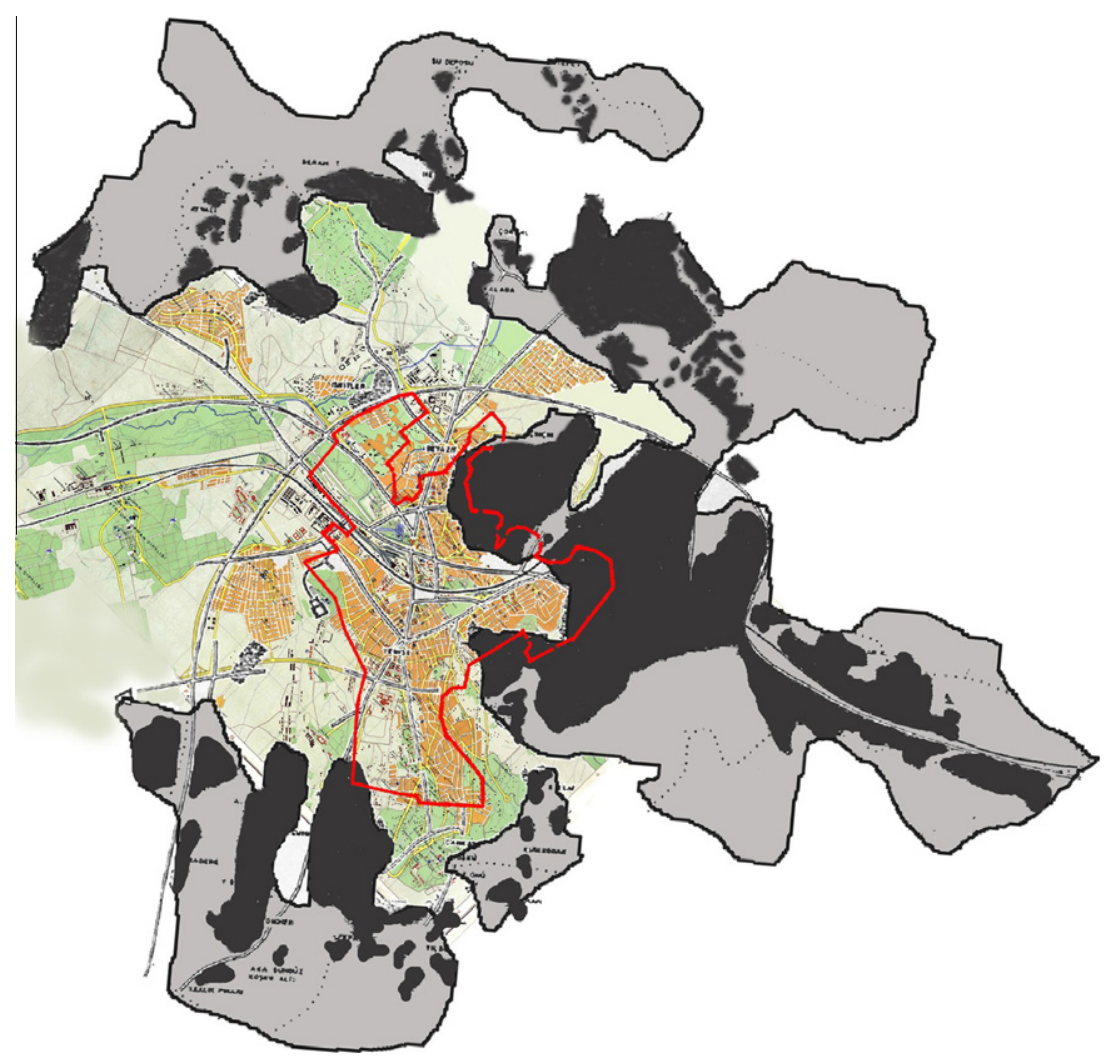

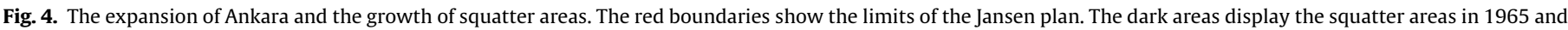

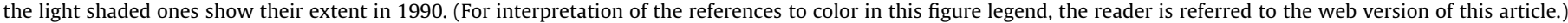

created, which served as a frontier between the core and the periphery. The most important outcomes of the plan were the suburban sprawl along the Western axis and the moving of industry out of the city center. While it was intended to build low-income housing through public investments in the northwest, private sector middle-class housing projects were encouraged in the southwest throughout the 1980s. The transfer of industrial production to the new industrial zones on the periphery continued throughout the 1990s. While $86 \%$ of industrial businesses were within a $10 \mathrm{~km}$. radius in 1988, by 2007 only $17 \%$ were within the $6 \mathrm{~km}$. radius. Between 1988 and 2007, 58\% of the industrial workforce moved out of the center to peripheral residential areas (Bostan, Erdoğanaras, \& Tamer, 2010, pp. 88-89).

Another enduring influence of the 1990 plan was the specialization of industrial zones. This was especially effective in the growth of electronics and high-tech military industry after the 1990s. These investments were also supported with the newly established technopolises within university campuses, promoting cooperation with industry. By the mid-1990s, Ankara was already the leader among Turkish cities in terms of the number of industrial patents (Armatlı-Köroğlu, 2006, p. 407).

Although the city developed in line with the decisions of the plan in the 1970s, the later years of the decade witnessed an urban crisis that marked all Turkish cities. Although the major dynamics of this crisis will be discussed below, it has to be noted that it was only one facet of an overall economic crisis that gradually assumed the form of social unrest in the country. Within the context of the Cold War, the accelerating social movements (which military intervention tried to suppress in 1971) ended with a military coup in 1980. This abolished the constitution, introduced a new (and anti-libertarian) one and severely curtailed civil rights. The upcoming years would witness gradual economic recovery making use of neoliberal strategies that made extensive use of urban space.
An important component of the transformation of urban development was the creation of Greater Municipalities resulting from the Metropolitan Act of 1984. Meanwhile the Master Plan Bureaus were closed down and their planning duties were transferred to the Greater Municipalities. During the 1980s, local development of residential zones was permitted by the Ankara Greater Municipality on the western and southern fringes of the city. This was the end of the controlled expansion of the city directed by the 1990 plan and the beginning of an uncontrolled sprawl, led by housing investments. Moreover, the scale of the sprawl increased in the 2000s. While it was the individual housing projects that guided the sprawl in the 1990s, the growth was directed by partial plan revisions covering larger areas in the following decade. Some of these revisions were later nullified by the courts due to their partial character (Ankara Greater Municipality, 2007a, p. 52). In 2005, Ankara's municipal borders were expanded and redefined within a radius of $50 \mathrm{~km}$. This meant that the area controlled by the municipality was enlarged by a factor of four (Fig. 5). Finally, a new plan targeting 2023 was approved by the Municipality in 2007.

\section{Transportation}

The incoming migration that escalated in the 1950s quickly rendered the existing public transport system inadequate. The newcomers soon invented their own solution in the form of dolmus, informal taxis carrying multiple customers. The dolmus system quickly became an indispensible component of the urban transport system. The first transportation study, which proposed a subway system for Ankara for the first time, was prepared in 1972. In the same year domestic car production began and the share of private cars in urban transportation reached that of mass transport in 1975 (Çubuk \& Türkmen, 2003, p. 127). Although the idea to build a 


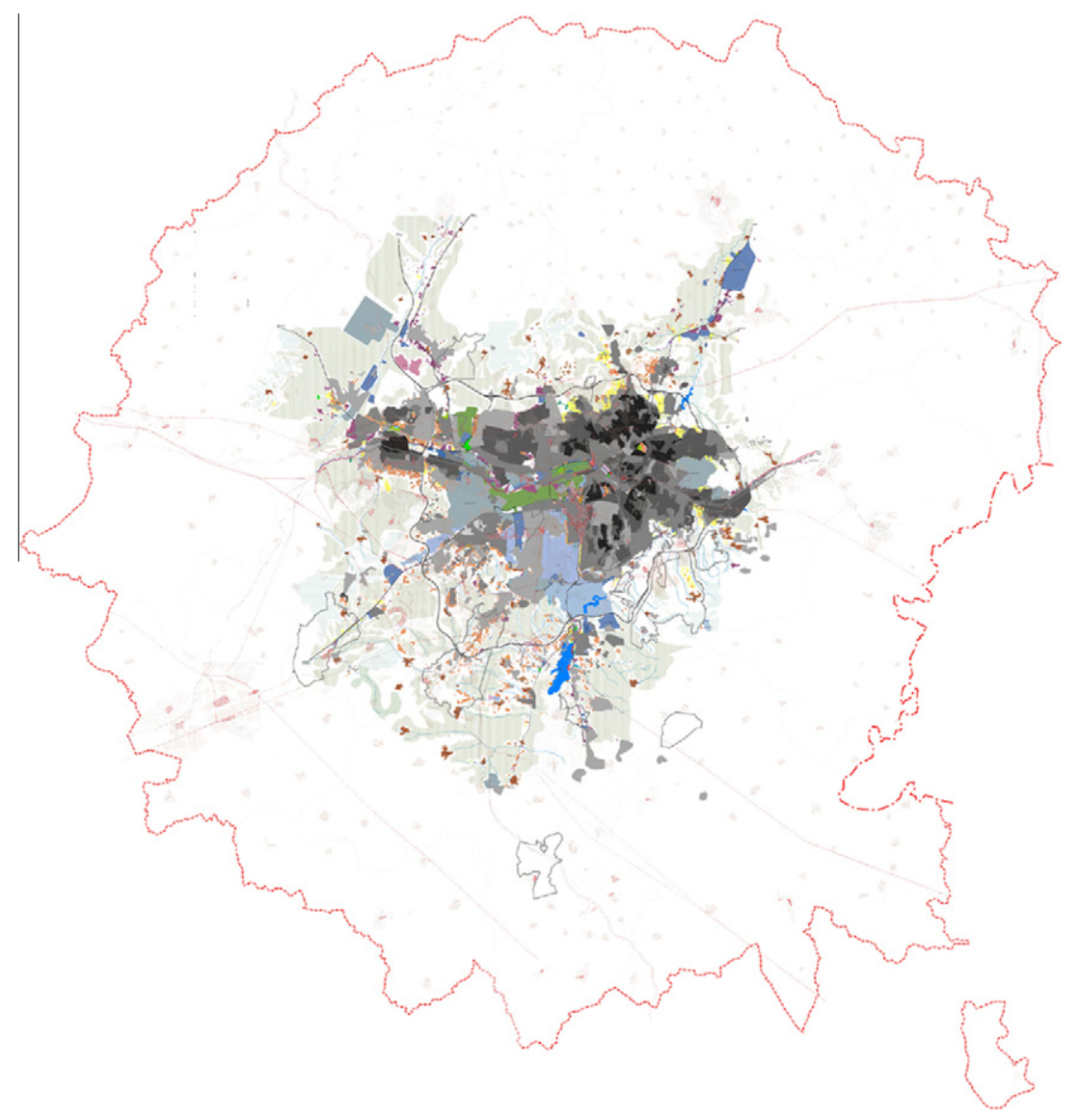

Fig. 5. The municipal borders and the current settlement pattern in 2005 (source: Ankara Greater Municipality).

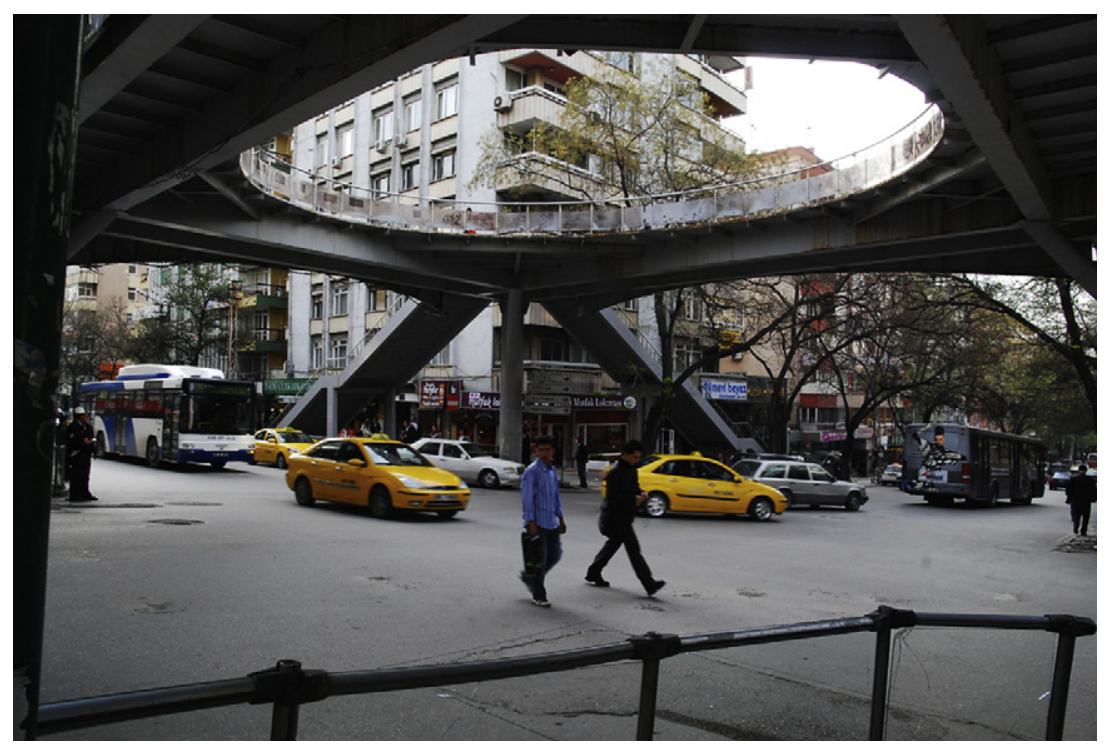

Fig. 6. An unused pedestrian overpass in downtown Ankara (source: Chamber of Architects Ankara Branch Archive).

subway line was often expressed, it was not possible due to economic constraints until the late 1980s.

In 1987, a comprehensive transportation study referring to the 1990 plan was finalized. Accordingly, a $55 \mathrm{~km}$. subway system was proposed, the first phase of which would consist of a line tying Kizılay to the new residential areas in the northeast. This $14.64 \mathrm{~km}$. line was begun in 1993 and finished in 1997. It was also supplemented with a $7 \mathrm{~km}$. light rail system running east-west across the city center in 1996. The Ankara Transport Master Plan, which proposed the construction of $130 \mathrm{~km}$. of rail system by 2015, was approved in 1994 (Çubuk \& Türkmen, 2003, pp. 136137). This was the last approved transportation plan made for the city. Although the construction of three subway lines was begun prior to the local elections in 2004, none was finished in 
Table 2

Number of motorized vehicles in Ankara.

\begin{tabular}{lcl}
\hline Year & Overall number of vehicles & Number of cars \\
\hline 2004 & 936,936 & 696,175 \\
2005 & 1008,546 & 798,690 \\
2006 & 1085,151 & 783,198 \\
2007 & 1143,379 & 820,355 \\
2008 & 1193,038 & 854,691 \\
2009 & 1234,695 & 887,703 \\
2010 & 1285,661 & 924,000 \\
2011 (August) & 1347,151 & 970,287 \\
\hline
\end{tabular}

2012. Moreover, the Greater Municipality handed over the construction of the lines to the government in 2011, on the grounds that the Municipal budget was not sufficient to finish the projects.

The urban sprawl marking the city's growth made traffic a major issue in the 1990s. The response of the Greater Municipality to this problem was to implement partial regulations, all of which encouraged vehicular traffic. Between 1994 and 2009, 109 vehicular bridges and tunnels were built and the main arteries tying the suburbs to the center were regularly widened. Within the same period, 93 pedestrian overpasses were built in the city, 17 of which were within the central hub (Öncü, 2009, p. 12). Pedestrian crossings were cancelled and pedestrians were forced to use overpasses (Fig. 6). The number of private cars increased 20\% between 2005 and 2009 and reached 887,703 , which corresponded to 191 private cars per 1000 persons in Ankara, the highest rate among Turkish cities (Table 2). In 2008, the share of public transport among Ankara's daily transportation modes was $69 \%$, with dolmuş still having a 22\% share and the subway system at only 7\% (Ankara Development Agency, 2011, p. 102).

Another development that went hand in hand with both the suburbanization process and the promotion of vehicular traffic in the recent years is the increase in the number of shopping centers in Ankara. The earliest in Ankara were located in the city center. After the opening of the first shopping center in 1989, only four more were opened in the following decade. During the 2000s, however, the number increased and they began to choose locations on the periphery. By the end of 2010, the number of shopping centers reached 28, and while the floor area per 1000 persons in Turkey is 82 square meters, this figure is 215 square meters for Ankara, which is higher than all of the European cities (Chamber of Architects Ankara Branch, 2011, p. 13).

\section{Local administration}

Traditionally, the results of local elections had always been consistent with the general elections in Turkey; hence, the municipalities were controlled by the party ruling the country. This pattern also supported the perception of the municipalities as local branches of the central government. Yet, in 1974, the resignation of the coalition government led by the RPP created a new situation, forcing the municipalities under the RPP to work in the face of constant obstacles from the right-wing Nationalist Front governments. ${ }^{5}$ The clash between the municipalities under the RPP and the Nationalist Front governments produced a demand for local autonomy for the first time in Turkish political history. Moreover, a leftist municipal program was developed, which advocated working class participation in decision-making processes and introduced measures reducing the cost of reproduction of urban labor power.

Ankara Municipality played a leading role among the RPP municipalities in developing the municipal program. This occurred

\footnotetext{
${ }^{5}$ Although the RPP was the party that established the republic, in the 1960s it declared its position at the "left of center".
}

for a number of reasons, the first of which was the existence of a network of state institutions, universities and professional organizations that housed left wing scholars and urban professionals in Ankara. ${ }^{6}$ These individuals worked in collaboration with the Municipality and at times directly took part as mayoral consultants. The second reason was that these experts worked in a relatively autonomous environment (in institutions such as the Ankara Master Plan Bureau) while their counterparts in Istanbul were under government pressure, due to global interest in Istanbul's investment opportunities.

As mentioned above, the municipalities were reorganized in the 1980s. The following era was characterized by the restructuring of local governments and the changing modes in the production of urban space. Both of these domains went through significant transformations, leading to the neoliberalization of the urban realm. As Brenner and Theodore (2002) have pointed out with the concept of "actually existing neoliberalism," even though by definition neoliberalism implicates a transnational mobility, as a structure it translates into different experiences, as constrained by different social and spatial limits. In this regard, it is necessary to detail this transformation, which is key to understanding the contemporary urban condition in Ankara.

In 1981, municipal revenues were raised with a new law and the 1984 "Metropolitan Act" further expanded these revenues. As mentioned earlier, the Greater Municipalities were granted planning powers within metropolitan areas that included a number of district municipalities. With such expanded powers and resources, the municipalities gradually became the major actors guiding large investments in urban space and urban services, which became in turn the major components of the urban economy. ${ }^{7}$ Contrary to the legacy of the social democrat experiments of the 1970s, the municipalities now chose to privatize collective consumption services that were previously provided publicly. This went hand in hand with the reduction of employment in the municipalities and the curtailing of social benefits of the municipal staff.

Some of the measures taken by almost all municipalities, beginning from the mid-1980s, which attracted private investments in urban economies, were the development of large areas at the fringes by private companies, large scale projects in housing and tourist resorts, the establishment of private schools and hospitals and the opening of shopping malls. Three main characteristics defined the neoliberal reorganization of the municipalities in this period: 1 . extensive privatization of municipal services such as garbage removal, street cleaning, maintenance of parks and public spaces, etc. 2. allocation of municipal funds to private investors via outsourcing, 3. use of unprecedented amounts of loans from national and foreign institutions (Doğan, 2008, p. 72-73).

In 1994, municipalities of 16 provincial centers and 6 metropolitan municipalities (including Ankara and Istanbul) were taken over by the Islamist Welfare Party. The party also won the general elections in 1995 and came to power with a coalition in 1996. However, the government was forced to step down by the military in 1997 and the party was closed down. In the 1999 local elections, the municipalities controlled by Islamist mayors -this time under the direction of the newly established Virtue Party - fell to 4 metropolitan municipalities (Ankara, Istanbul, Kayseri, Konya) and 12 provincial centers. Nevertheless, as a consequence of these two successive elections, from 1994 to 2004, almost half of the urban population in Turkey lived in cities controlled by Islamist local

\footnotetext{
${ }^{6}$ For the discussion of the political agency of urban professionals in Tukey, see Batuman (2008).

7 Scholars have defined the post-1980 period in Turkey as marked by "urbanization of capital" (Sengül, 2001), "the transition from the city of petty capital to the city of big capital," (Tekeli, 1982), and "the transition from smooth, integrative urbanization to tense, exclusionary urbanization” (Işık \& Pınarcıŏ̆lu, 2001).
} 
governments. After 2004, this ratio would become even more pronounced. When the Virtue Party was in turn closed down, the Islamist movement split. While a group continued with traditional Islamist arguments, a moderate faction established the Justice and Development Party, which came to power in the general elections in 2002. The JDP also had a sweeping victory in the 2004 local elections, winning 59 provincial centers out of 81 and 12 of 16 metropolitan municipalities. The party maintained its dominance in urban and national politics afterwards, with successive electoral victories in 2007, 2009 and 2011.

The gradual rise of Islamism as a political force in Turkey has to be understood in three phases: 1 . early years of the 1990s in which Islamism emerged as a radical movement by organizing especially among the urban poor, 2. 1994-2002 when the major cities came under the rule of Islamist mayors, 3. post-2002, the JDP coming to power and the increasing dominance of neoliberal accumulation strategies over Islamist ideological inclinations. In the first phase, the neoliberal restructuring characterized by privatizations, the precarization of labor, as well as the chronically high level of inflation all resulted in increasing impoverishment, especially in the big cities. While mainstream political parties remained impervious to urban poverty, the Islamist cadres actively worked within the squatter areas and established a network of aid and solidarity in the early 1990s (Tuğal, 2006; White, 2003). While this strategy allowed them to gain control of local administrations in the major cities, they utilized this power to further improve their aid network as an original "welfare system" in the second phase. Municipalities under the WP began to systematically distribute coal, food, bread and clothing to households during the 1990s. Especially in the early years, the economy created by these aids was disorganized and shady. The control of aid distribution was handled together with Islamist associations and through the municipalities' charity funds, which blurred the flow of municipal funds and obscured their monitoring. The lack of transparency was also true of the donations made by businessmen to the municipalities' charitable funds and the favors granted in exchange (Buğra, 2007, p. 47). In the final phase, that is after JDP's coming to power in 2002, this welfare system was formalized and integrated within the state functions. With new legislation enacted in 2004, metropolitan municipalities were assigned responsibilities and granted new powers to provide social services and aid. Yet, the crucial aspect of this final episode is the primary role of accumulation strategies depending on the production of urban space, rendering Islamist solidarity secondary.

The rise of Islamists to power in Turkey owed very much to the urban politics they have utilized. A major social force that supported the Islamist parties was the local bourgeoisie in small Anatolian towns that enjoyed rapid development in connection with the global market. While old industrial centers declined, these new centers appeared as emerging industrial zones working in close contact with the local administrations in their respective localities. Small and medium scale firms working in labor-intense fields built coalitions at the city scale and grew in mutual relationship with the municipalities. In larger cities with reduced industrial capacities, similar alliances tying the municipalities to local investors also developed in two major fields: the municipal welfare system itself, and the production of urban space with urban regeneration projects. As I will discuss urban regeneration within the topic of housing, here I shall continue with the political economy of aid distribution.

The distribution of aid in Ankara was handled with the methods similar to those used by other municipalities. In the early years, the Islamist associations were involved in the process both as favored receivers of aid and as means of distribution. Unlicensed substandard coal confiscated by the municipality was distributed to these associations as well as the squatters (which resulted in noticeable

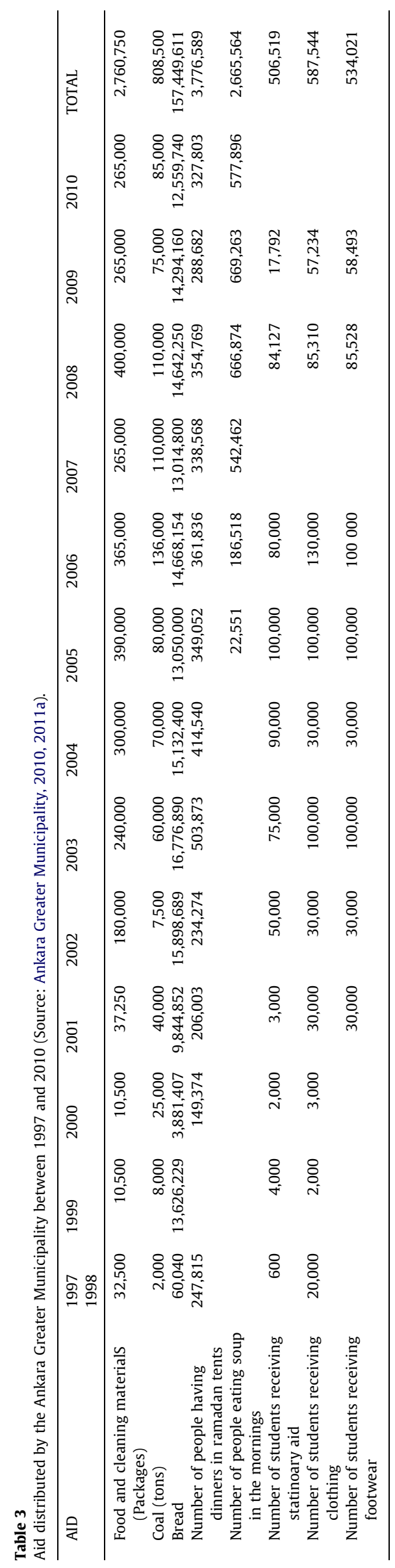


increases in air pollution in the mid-1990s). The size of the aid as well as its organization gradually expanded (Table 3 ). In addition to the aid, centers were established to serve children, the elderly and the disabled; these centers served 20,000 children, 14,000 senior citizens and 16,000 with disabilities, between 1994 and 2004 (Daniş \& Albayrakoğlu, 2009, pp. 103-104).

The supply of goods to be distributed to the urban poor from the local market integrates not only the squatters but also the petty producers, dealers, power brokers and even in-city transportation companies to this power network at the center of which rests the municipality. This cycle, then, reproduces a successful hegemonic network linking both local businesses and the urban poor through the utilization of municipal funds. Nevertheless, the cost of this cycle is immense. As the urban poor receive some compensation, these high prices mostly hit the middle-classes, incidentally the most persistent opposition group to the Islamists. Moreover, since the revenues of the municipalities are not enough to pay for this economy, their chronic budget deficits are overlooked by the government. Especially after the JDP's coming to power in 2002, the municipalities under the party's control were in practice allowed to disregard their debts to the Treasury.

In terms of handling the economic burden of the aid system, the Ankara Greater Municipality was much more negligent than the others. The actual living costs, especially the prices of urban services such as public transportation, water and natural gas, are the highest among all Turkish cities. Moreover, especially after JDP's coming to power in 2002, the Ankara Municipality has consistently been the first in the Treasury's list of debtors. In 2007, the municipality owed 3.8 billion TL ( $\$ 2.9$ billion) to the Treasury while the overall debts of the municipalities were 12.9 billion TL. By June 2010, these figures reached 4.7 and 14.6 billion, respectively. Considering that the Municipality's 2010 budget was 2.27 billion TL, the level of debt becomes clearly visible. In 2006, the debts of the Ankara Municipality to BOTAŞ, the national natural gas company, became a topic of public debate as it caused the company to raise gas prices. During the summers of 2006 and 2007, Ankara witnessed drought although the amount of precipitation was not below seasonal trends. It quickly became apparent that the main reason was the failure of the Municipality to realize investments in water systems proposed by State Water Works for years (Yıldız, 2009, p. 75). As mentioned above, a major failure in terms of infrastructural investments was the handing over of the three unfinished subway lines to the Ministry of Transportation in 2011. Despite these very obvious defects, the urban hegemony established by the municipality managed to keep the mayor in office for a fourth term in the 2009 local elections.

\section{Housing}

The intensifying urbanization brought about extreme levels of land speculation with drastic increase in land values in Ankara in the 1950s. With increased infrastructure costs, it became virtually impossible for the middle-income groups to own a house in the city center, thus they settled in the areas with appropriate land prices. In the absence of flat ownership, it was not possible for individuals to build high rise apartment blocks single-handedly. Within this context, small contractors organizing the capital of a number of individuals emerged as important agents of urban development. In the absence of an advanced sector with large-scale capital and high construction technology, they performed low-capital intensive activities with non-unionized, low wage labor. Taking advantage of high inflation, cheap labor as well as the continuous demand for housing, they made high profits in the short run (Öncü, 1988, pp. 50-53). ${ }^{8}$

\footnotetext{
${ }^{8}$ For a discussion of the politics of housing in the 1970s, see Batuman (2006).
}

While the small contractors served the urban middle-classes, squatting emerged as the informal housing method and a survival strategy for the urban poor. These two primary methods of housing production, namely the construction of apartments by small contractors and the self-help gecekondus of the squatters, dominated the urbanization process in Turkish cities up until 1980s. Both of these spontaneous processes were regulated by the state in the mid-1960s (Tekeli, 1993, p. 6-7). The 1965 "Flat Ownership Act" for the first time organized the ownership of apartments in a single building, further facilitating housing production by small contractors. The 1966 "Gecekondu Act", on the other hand, proposed certain measures recognizing the existence of squatter settlements and trying to avoid the building of new ones. Nevertheless, the Act was unsuccessful in preventing the expansion of squatter settlements. While the number of squatter houses in Ankara was estimated at 70,000 in 1960, the number reached 240000 in 1980. The squatter population rose from 250000 to 5750000 between 1955 and 1980 , which corresponded to $4.7 \%$ and $26.1 \%$ of the urban population nationally. By the 1960s, the number of squatters reached half of the urban population in the five largest cities (Keleş, 2004, pp. 561-563). In $1965,65 \%$ of the urban population in Ankara was living in squatter settlements (Akçura, 1971, p. 57).

By the mid-1970s, the supply of land in Ankara's center, as well as its immediate surroundings, had been depleted. This was due to the high-rise residential developments in the center and the purchase of peripheral lots by large companies. This shortage was reflected in land prices as well as house rents, raising both. Meanwhile, the cost of construction materials escalated enormously. And finally, the high rate of inflation that used to be beneficial for the contractors reached a level which required increased rates of cash down-payments and installments (Tekeli, 1982; Öncü, 1988). Under these conditions, it became impossible-that is, unprofitable-for small contractors to serve the urban middleclasses. The process of squatting was also experiencing a bottleneck. As squatting was characterized by the occupation of land, its absence around the cities made it impossible to find places to occupy. While small contractors could not find lots to build, large companies preferred land speculation which was more profitable than housing production. That is, all channels of housing production were blocked towards the end of the 1970s.

This bottleneck in housing production was overcome through suburbanization on the western fringes and the surplus rent created by the transformation of squatter areas. As mentioned above, Ankara had already begun to develop to the west and this development was directed by private developers, especially in the southwest. During the process of sprawl, the upper classes deliberately left the city core for the suburbs. The middle classes were also involved in the suburban move especially via housing cooperatives, which worked as a means of distribution of urban rent in the second half of the 1980s. In the meantime, the gecekondu were transformed into a commodity with building amnesties turning the squatters into true land speculators. This transformation was especially encouraged by the amnesty in 1984 , which led to a comprehensive redevelopment of squatter areas in the form of 4 and 5 storey apartments. While the squatters were given shares from the surplus rent, this renewal trend contributed to the recovery of small scale contractors (Türel, 1994). Urban space was used as a means for economic recovery and a tool for the politics of clientelism.

In 2004, urban regeneration became a legal term in Turkish legislation. A Law was passed specifically for Ankara, which defined an urban regeneration project for the squatter areas in northern Ankara. According to the project, an area of 16 million square meters containing 10,500 gecekondus was to be redeveloped. The evacuation process was rather peaceful since the squatters were promised to move in by 2008 , although none has moved in since 
Table 4

TOKI Projects in Ankara between 2003-2010 (Source: TOKI, 2011a, 2011b).

\begin{tabular}{|c|c|c|c|c|c|c|c|c|c|c|c|c|}
\hline $\begin{array}{l}\text { Level of } \\
\text { completeness }\end{array}$ & $\begin{array}{l}\text { Number of } \\
\text { projects }\end{array}$ & Schools & Gyms & Dormitories & $\begin{array}{l}\text { Local } \\
\text { healthcare }\end{array}$ & Hospitals & $\begin{array}{l}\text { Trade } \\
\text { centers }\end{array}$ & Mosques & Libraries & Nurseries & $\begin{array}{l}\text { Social } \\
\text { facilities }\end{array}$ & $\begin{array}{l}\text { Housing } \\
\text { units }\end{array}$ \\
\hline $100 \%$ & 48 & 23 & 10 & & 5 & & 13 & 9 & 2 & 3 & 3 & 17,739 \\
\hline $96-99 \%$ & 39 & 23 & 6 & 1 & 7 & & 16 & 14 & 3 & 3 & & 19,929 \\
\hline $50-95 \%$ & 51 & 15 & & & 1 & 4 & 10 & 8 & & 1 & 7 & 18,232 \\
\hline $1-49 \%$ & 36 & 19 & 1 & & & 1 & 4 & 7 & & & 3 & 5,480 \\
\hline Total & 174 & 80 & 17 & 1 & 13 & 5 & 43 & 38 & 5 & 7 & 13 & 61,380 \\
\hline \multicolumn{2}{|c|}{ Total number for Turkey } & 686 & 715 & 67 & 88 & 183 & 407 & 319 & 38 & 7 & 69 & 500,000 \\
\hline
\end{tabular}

the buildings were not finished as of late 2011. It is planned to construct 8100 houses for the squatters themselves and 21,000 extra units. A large portion of the project area was defined exclusively as an upper class residential zone with a vast recreation area (Gümüş, 2010, p. 18). In 2005, new legislation was introduced that would allow the renewal of "degraded historic sites" which would effectively pave the way for the gentrification of the old center. In the same year, the Municipalities Act was renewed and Greater Municipalities were granted powers to plan and redevelop areas deemed necessary. In 2010, these powers were further expanded.

In 2003, TOKI, the Housing Development Administration, which was established in 1984 with the objective to construct social housing, was granted new powers. Accordingly, the Administration was allowed to establish companies, execute projects to create new funds, and use public land without charge. With a series of regulations, institutions and administrations responsible for housing and land development (such as the Undersecretariat of Housing and the Land Office) were closed down and their duties and assets were handed over to TOKI. In 2004, the administration was granted planning authority in the areas that would be redeveloped. Moreover, with the same legislation, it gained the power to determine the value of expropriation in squatter areas. In 2007, the duties
Table 5

Urban Regeneration Projects of Ankara Greater Municipality. (Source: Ankara Greater Municipality, 2011b).

\begin{tabular}{lll}
\hline Year & Number of projects & Total area (ha) \\
\hline 2005 & 21 & $13,042,80$ \\
2007 & 45 & $29,911,73$ \\
2010 & 55 & $34,284,80$ \\
\hline
\end{tabular}

of the Ministry of Public Works regarding gecekondu prevention and slum clearance were also transferred to TOKI. With these regulations, the administration became exempt from almost all of the bureaucratic mechanisms and could freely expropriate, plan and redevelop areas. Moreover, it became the major actor in housing production and the main facilitator of public private partnership. As a result, the number of houses built by TOKI between 2003 and 2010 reached 500 000, while this number was merely 43,000 for the period 1984-2003 (TOKI, 2011a). In addition, the Administration undertook construction activities to raise funds wherever it deemed profitable.

TOKI has been involved in the urban regeneration projects pursued by both Ankara Greater Municipality and the district municipalities in the city. The projects implemented in Ankara by TOKI

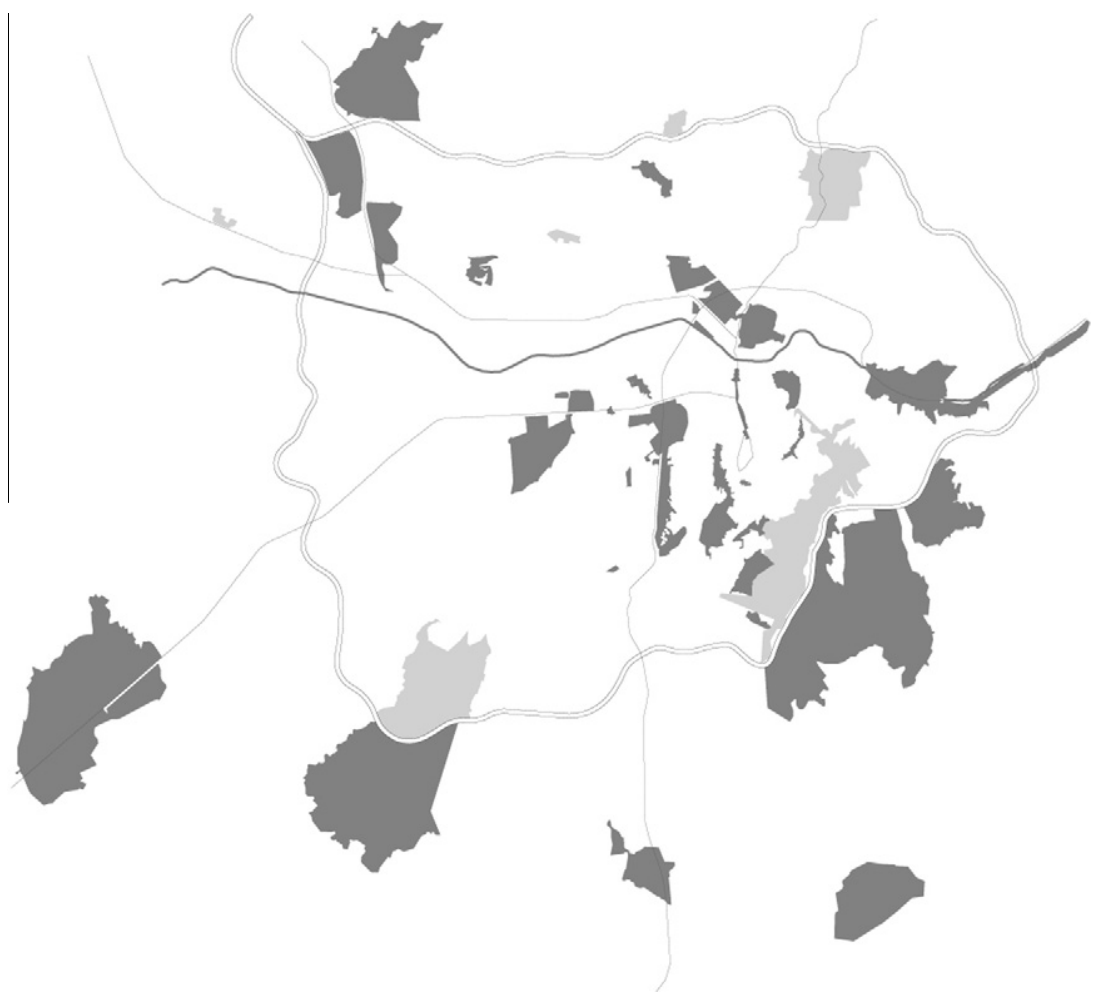

Fig. 7. The urban regeneration zones in Ankara (source: Sargın, 2012) 


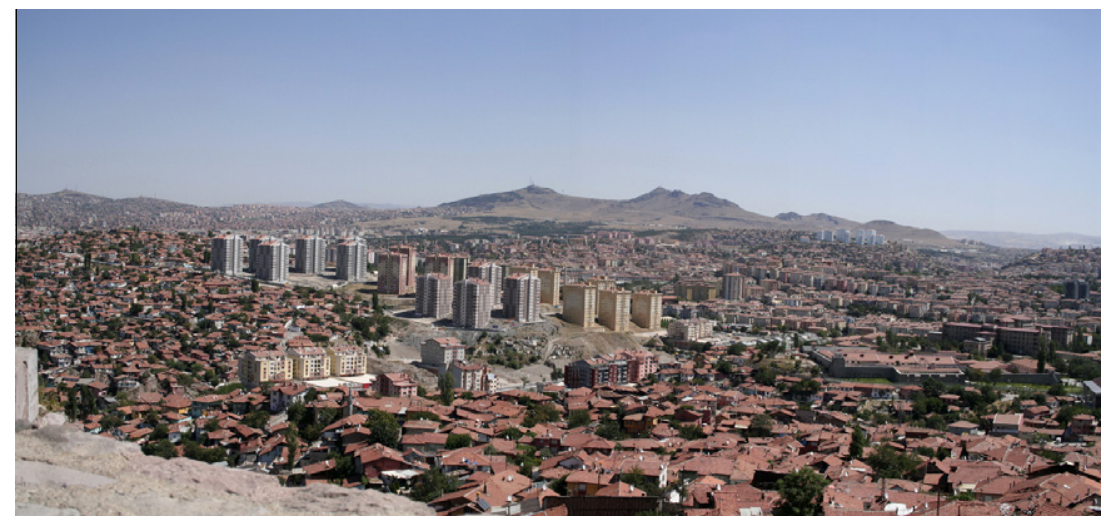

Fig. 8. High-rise blocks built by TOKI in the squatter areas (source: Chamber of Architects Ankara Branch Archive).

are listed in Table 4 (Ankara Greater Municipality, 2007b; TOKI, 2011a, 2011b). Nevertheless, there are also projects that do not yet have clear data regarding the facilities to be built. These projects are only defined with their "regeneration zones" as delineated by the decrees of the Municipal Assembly (Table 5). The total area classified as regeneration zones by Ankara Greater Municipality is currently more than 34,000 ha., which is approximately $14 \%$ of the metropolitan area (Fig. 7). It is clearly visible that urban regeneration has become the predominant apparatus of space production, which has significantly changed the scale of urban development, thus rendering independent small contractors outmoded. Public land is developed with the collaboration of TOKI and respective municipalities, expropriation of squatter areas is pursued on terms defined by these agents and the surplus rent is redistributed to private investors undertaking construction. Meanwhile, squatters are left with the choice to either move out or use the expropriation money as a downpayment and take TOKI loans to own a new apartment in the same area. Hence, the major aspect of this strategy is the immense powers vested in TOKI and the greater municipalities, which results in two striking consequences: the maximization of profit and the lack of public participation in decision-making processes. The disregard for environmental concerns and the demands of inhabitants living in the regeneration areas have been major issues of criticism and led to the cancellation of a significant portion of these projects by courts (Fig. 8). The court rulings, in turn, led to new legislation expanding the legal powers of TOKI and the municipalities.

In sum, three main methods can be identified in the urban regeneration projects pursued in Ankara. The first method is the development of hitherto undeveloped land on the fringes. The second method is the renewal of public spaces and historic sites in the urban core, especially the old center of Ulus and the open spaces that were created with the Jansen Plan. These are subject to regeneration proposals, which are hot issues resulting in a legal struggle between the municipality and professional organizations. The third method is the evacuation and redevelopment of squatter areas which were once peripheral but now remain within the city and have gained value due to urban sprawl (Güzey, 2009). Here, the powers vested in the municipality materialize in the form of coercion against the squatters. The municipal authority embarks upon signing individual contracts with each household in the area, and hence by instigating the atomization of the squatters, creates an extreme case of "regeneration sans participation."

The transformations of gecekondu areas have led to serious clashes between the municipality and the squatters resisting evacuation. Especially in the traditional squatter districts of Ankara, squatters have organized and demanded participation in the decisions regarding the regeneration projects. While in some examples the squatters succeeded in negotiating more advantageous terms, in some cases they managed to cancel the projects through court decisions. In some districts the Municipality attempted to evacuate neighborhoods by force, which was met by resistance. In such areas, the tension prevails. ${ }^{9}$

\section{Conclusion: urban politics at large ${ }^{10}$}

The urban history of Ankara throughout the 20th century displays a gradual move away from planned and controlled development. Following the city's declaration as the Turkish capital, attempts were made to build a modern city that would serve as a model for urban development across the country. Yet the continuous migration on the one hand and the pressure of land speculation on the other significantly reduced the effectiveness of plans, as well as the institutions responsible for controlling urban growth to conform to these plans. As a result, especially in the postwar era, the city witnessed rapid spontaneous growth and the endeavors to cope with it. This trend came to an end after the 1980s, with the abandonment of the determination to control urban development. Although planning prevailed as a legal obligation, partial revision plans and plan modifications have become significant means to get around limitations. It is crucial to note that although this tendency gained impetus in the recent years, it is by no means peculiar to the current administration. For instance, 3954 revision plans and modifications were approved in Ankara between 1985 and 2005, which corresponds to an average of 200 modifications per year (Şahin, 2007, p. 208). As this figure illustrates, the failure of holistic planning efforts has been a significant issue that precedes the current government and the present mayor.

Nevertheless, the Islamist success in urban politics opened a new era characterized by the juxtaposition of neoliberal policies and social welfare mechanisms. This model made it possible to ease the impoverishing effects of neoliberalization and also strengthened the Islamist networks within civil society. While all the cities were ruled in the same fashion, there were also differences resulting from the historical specificities of individual cities. In this regard, it has to be noted that certain peculiarities identified with the personality of Mayor Gökçek, who has been ruling Ankara since 1994, are worth mentioning. The distinguishing feature of Gökçek's administration has been his pragmatic rather than doctrinaire interpretation of Islamism. While other WP mayors attempted to implement radical policies and made public

\footnotetext{
${ }^{9}$ For examples of such stories, see the web site of the "Right to Shelter Bureau" established in Dikmen Valley, the site of an ongoing clash over the regeneration of the area: http://www.dikmenvadisi.org/.

${ }^{10}$ The discussions in this section have previously appeared in Batuman (2009b)
} 

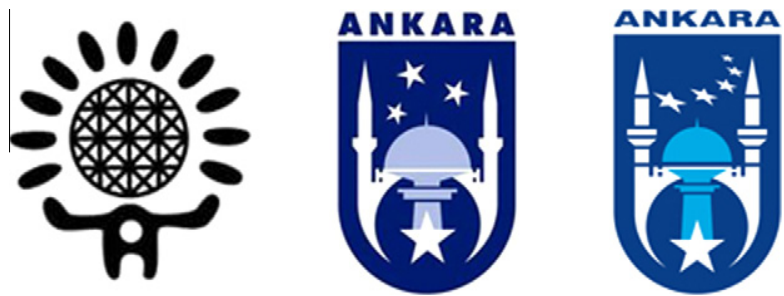

Fig. 9. The city emblems of Ankara. The stylized version of the Hittite sun disk began to be used as the city emblem in 1973. It was replaced with the second emblem, superimposing a mosque silhouette and Atakule, a landmark that dominates the city's skyline, in 1995. The continuous public debate resulted in the cancellation of this emblem by a court order in 2009. Nevertheless, the mayor declined to use the old emblem and produced this version in 2011.

statements referring to Islamic rules, especially in their first term, Gökçek's pragmatism functioned as a galvanizing force, bringing together different strands of the Turkish right under the umbrella of Islamist discourse. The key to Gökçek's pragmatic populism was embedded in the urban collective memory of Ankara. As shown earlier, Ankara was the locus of the republican project of modernization and for long has been the national symbol of this modernization effort. It was also the major setting of the 1970s efforts in social democratic municipal governance. Hence, the ideological discourse of the Gökçek era has depended upon a reaction to both the radical modernization efforts of the early republican period (especially on the part of Islamists) and to the 1970s leftist movements (especially on the part of anti-communist nationalists). ${ }^{11}$ Building his performance on political tension, Mayor Gökçek has constantly clashed with opposition groups (including NGOs, professional organizations, universities and even district municipalities) as well as the administrative courts cancelling his projects, accusing them of acting "ideologically." 12

An overall evaluation of the role played by the municipality in the current urban condition in Ankara reveals the increasing power of the local administration over social relations in the city. The urban regeneration projects and the municipal welfare system emerge as instruments creating an imbalanced power relation between the municipality and the urban residents. Within the urban regeneration processes, the local government assumes the role of an authoritarian executive power rather than being a participatory domain of urban politics. On the one hand it reallocates funds through the distribution of aid and the large scale regeneration projects; on the other, it compensates the living costs of the urban poor with its welfare system. As this redistribution network supports the political hegemony of the Islamist administration, those raising demands regarding issues of collective consumption appear as dissidents harming social coherence.

The crucial point regarding the municipal welfare system is precisely the opacity of the selection of both the providers and the receivers of aid. While such opacity serves the utilization of this system for clientelistic partisanship, it also creates the impression that the social aid provided by the municipality is the result of benevolence (of the mayors) rather than the fulfillment of citizens' rights. As underlined by Buğra (2008), social policies that are based upon charity conceal the fact that in essence they are rights born

\footnotetext{
11 Doğan (2005) uses the term "revanchism" to define Mayor Gökçek's ideological performance, cf. Neil Smith's (1998) use referring to Mayor Giuliani's administration in New York.

12 A significant case of Gökçek's antagonistic attitude was his changing of the city emblem with the support of right-wing members of the municipal assembly. The old emblem referring to ancient Anatolian civilizations was replaced with a stylized mosque silhouette. Despite public protests and a court order cancelling his new emblem, Gökçek refused to re-use the old emblem and recently introduced a third emblem, which is a replica of the earlier one with small changes in the details (Fig. 9).
}

out of popular struggles. This, in return, destroys consciousness regarding the right to the city and the public life that requires citizens' participation as organized interest groups raising demands. The result is the emergence of a "precarious publicness" (Doğan, 2008), within which participation in the urban social life is no longer defined by urbanites' political rights and free will, but through a hegemonic network of subordination that captures them.

It has to be noted that this new urban hegemony exists within actual spaces of the city; that is, the production of space also contributes to the making of this hegemony. As Islamic neoliberalism, and the urban condition it has produced, transformed public life, the very same transformation is further supported by spatial instruments. The city, which should have been understood as a network of public spaces, is rapidly turning into another sort of network, in which the rich and the poor built their own ghettoes and fortified themselves with their own kind, creating distinct patterns of consumption (Akpınar, 2009). On the one hand, suburban neighborhoods are rising as enclosed socio-spatial systems, and new gated communities sprawl on the erstwhile urban periphery with unprecedented speed. On the other hand, the urban core is being emptied, wherein both the functions of the center and the gecekondu population, residing in areas that are deemed unfit by the authorities, are pushed out of the city's heart. While squatters are denied participation in the decision processes regarding their own living environments, public spaces deteriorate parallel to the decline of the city center. The basic identity of the urbanite, being a pedestrian, is negated in the city center; the downtown is prepared for new urban transformation cycles by rendering it unsafe.

The production of space is currently a process that has achieved a life of its own in Ankara. Neither housing projects, nor traffic investments, nor even the construction of shopping centers follow any kind of plans or projections based on the actual needs of the urban population. Although the city is enjoying a period of economic development founded on the exploitation of urban space, the city as a social entity is suffering disintegration. This dual trend seems to last until the economic cycle becomes unsustainable.

\section{References}

Akçura, T. (1971). Ankara: Türkiye'nin Başkenti Hakkinda Monografik Bir Arastırma [Ankara: A Monographic Study on the capital of Turkey]. Ankara: METU Faculty of Architecture Press.

Akpınar, F. (2009). Sociospatial segregation and consumption profile of Ankara in the context of globalization. METU Journal of the Faculty of Architecture, 26(1), $1-47$.

Ankara Development Agency (2011). Istatistiklerle Ankara 2011 [Ankara in Statistics 2011]. Ankara: Ankara Development Agency.

Ankara Greater Municipality (2007a). Ankara 2023 plan report. Ankara: Ankara Greater Municipality.

Ankara Greater Municipality (2007b). Urban regeneration projects. Ankara: Ankara Greater Municipality.

Ankara Greater Municipality (2010). 2010 Mali Faaliyet Raporu [2010 Annual Financial Report]. Ankara: Ankara Greater Municipality.

Ankara Greater Municipality (2011a). 1997-2010 Yılları Arasında Yapılan Yardımlar [Aid distributed between 1997-2010]. <http://www.ankara.bel.tr/AbbSayfalari/ Sosyal_Hizmetler2/Sosyal_Hizmetler_Ana.aspx> Accessed 25.07.11.

Ankara Greater Municipality (2011b). Kentsel Dönüšum Projeleri [Urban Regeneration Projects]. <http://www.ankara.bel.tr/AbbSayfalari/Projeler/ emlak/kaynak_gelistirme_2/kaynak_gelistirme_2.aspx> Accessed 25.07.11.

Armatlı- Köroğlu, B. (2006). Sanayi Bölgelerinde KOBì Ağları ve Yenilik Süreçleri [Networks of Small and Mid-size Firms and Innovation Processes in Industrial Zones]. In A. Eraydın (Ed.), Değişen Mekan: Mekansal Süreçlere Illişkin Tartışma ve Araştırmalara Toplu Bakış, 1923-2003 [The Changing Space. A Look at the Debates and Researches on Spatial Processes, 1923-2003] (pp. 397-420). Ankara: Dost.

Batuman, B. (2006). Turkish urban professionals and the politics of housing, 19601980. METU Journal of the Faculty of Architecture, 23(1), 59-81.

Batuman, B. (2008). Organic intellectuals of urban politics? Turkish urban professionals as political agents in 1960-1980. Urban Studies, 45(9), 1925-1946.

Batuman, B. (2009a). The politics of public space. Domination and appropriation in and of Kızılay Square. Saarbrücken: VDM Verlag. 
Batuman, B. (2009b). Hasar Tespiti: Ankara'da Neoliberal Belediyeciliğin Bilançosu [Damage Report: The Balance sheet of neoliberal municipality in Ankara]. Dosya, 13, 3-7.

Bostan, M., Erdoğanaras, F., \& Tamer, N. G. (2010). Ankara Metropoliten Alanında İmalat Sanayinin Yer Değiștirme Süreci ve Özellikleri [Relocation Process and its Characteristics in manufacturing Industry Firms in Ankara Metropolitan Area]. METU Journal of the Faculty of Architecture, 27(1), 81-102.

Brenner, N., \& Theodore, N. (2002). Cities and the Geographies of 'Actually Existing Neoliberalism'. In N. Brenner \& N. Theodore (Eds.), Spaces of Neoliberalism: Urban Restructuring in North America and Western Europe (pp. 2-32). Oxford: Blackwell.

Buğra, A. (2007). Poverty and citizenship: An overview of the social-policy environment in Republican Turkey. International Journal of Middle East Studies, $39,33-52$.

Buğra, A. (2008). Kapitalizm, Yoksulluk ve Türkiye'de Sosyal Politika [Capitalism, poverty and social policy in Turkey]. Istanbul: Iletişim.

Cengizkan, A. (2004). Ankara'nın Illk Planı: 1924-25 Lörcher Planı [The First plan of Ankara: 1924-25 Lörcher Plan]. Ankara: Ankara Enstitüsü Vakfi.

Cengizkan, A. (2005). 1957 Yücel-Uybadin İmar Planı ve Ankara Sehir Mimarisi [1957 Yücel-Uybadin Plan and the urban architecture of Ankara]. In T. Şenyapılı (Ed.), Cumhuriyet'in Ankara'sı: Özcan Altaban'a Armağan (pp. 24-59). Ankara: METU Press.

Chamber of Architects Ankara Branch (2011). Ankara Raporu 2000-2010: Son On Yllda Mimarlk ve Kentleşme [Ankara Report 2000-2010: Architecture and urbanization in the last ten years]. Ankara: Unpublished Report, Chamber of Architects Ankara Branch.

Çubuk, M. K., \& Türkmen, M. (2003). Ankara'da Raylı Ulaşım [Rail Transport in Ankara]. Gazi Üniversitesi Mühendislik ve Mimarlk Fakültesi Dergisi, 18(1), 125-144.

Danis, M. Z., \& Albayrakoğlu, S. (2009). The social dimensions of local governments in Turkey: Social work and social aid, a qualitative research in Ankara Case. Humanity \& Social Sciences Journal, 4(1), 90-106.

Doğan, A. E. (2005). Gökçek'in Ankara'yı Neo-Liberal Rövanşçlıkla Yeniden Kuruşu [Gökçek's remaking of Ankara through neoliberal revanchism]. Planlama, 4 $130-138$.

Doğan, A. E. (2008). Eğreti Kamusallk: Kayseri Örneğinde İslamcl Belediyecilik [Precarious Publicness: Islamist municipality in the case of Kayseri]. Istanbul: Illetişim.

Gümüş, N. A. (2010). Neoliberal Politikanın Kent Mekanındaki Yansıması: Kuzey Ankara Kent Girişi Projesi [The reflection of neoliberal policy in urban space. North Ankara City entrance Project]. Dosya, 21, 16-21.

Güzey, Ö. (2009). Urban regeneration and increased competitive power: Ankara in an era of globalization. Cities, 26, 27-37.

Işık, O., \& Pınarcıoğlu, M. (2001). Nöbetleşe Yoksulluk: Sultanbeyli Örneği [Poverty in Turns: The case of Sultanbeyli]. Istanbul: İletişim.

Keleş, R. (2004). Kentleşme Politikası [Urbanization Policy] (8th ed.). Ankara: İmge
Keles, R., \& Danielson, M. N. (1985). The Politics of Rapid Urbanization; Government and Growth in Modern Turkey. New York: Holmes \& Meier.

Keyder, Ç. (1987). State and Class in Turkey. London: Verso.

Öncü, A. (1988). The politics of the urban land market in Turkey: 1950-1980. International Journal of Urban and Regional Research, 12(1), 38-64.

Öncü, M. A. (2009). Yetmişli Yıllardan Günümüze Ankara Kent Yönetimlerinin Ulaşım Politikaları ve Uygulamaları [Transportation policies of local administrations in Ankara since the 1970s]. Dosya, 11, 4-19.

Roberts, B. R. (1989). Urbanization, migration and development. Sociological Forum, 4(4), 665-691.

Sahin, S. Z. (2007). The Politics of Urban Planning in Ankara between 1985 and 2005 Unpublished PhD. Ankara: Dissertation, Middle East Technical University.

Sargın, G. A. (Ed.). (2012). Ankara Kent Atlası [Ankara City Atlas]. Ankara: Chamber of Architects Ankara Branch.

Sengül, T. (2001). Kentsel Celişki ve Siyaset: Kapitalist Kentleșme Süreçleri Üzerine Yazllar [Urban Conflict and Politics: Writings on capitalist urbanization]. Istanbul: Demokrasi Kitaplığı.

Şenyapılı, T. (2004). "Baraka"dan Gecekonduya: Ankara'da Kentsel Mekanın Dönüsümü 1923-1960 [From shack to gecekondu: Transformation of urban space in Ankara 1923-1960]. Istanbul: İletişim.

Smith, N. (1998). Giuliani time: the revanchist 1990s. Social Text, 16(4), 1-20. Winter.

Tankut, G. (1994). Bir Baskentin Imarı - Ankara: 1923-1939 [The Construction of a capital - Ankara: 1923-1939]. Istanbul: Altın Kitaplar.

Tekeli, İ (1982) Türkiye'de Konut Sorununun Davranışsal Nitelikleri ve Konut Kesiminde Bunalım [Behavioral aspects of housing question in Turkey and crisis in the housing sector]. In Konut '81, Kent-Koop (pp. 57-101), Ankara.

Tekeli, i (1993) Yetmiş yıl içinde Türkiye'nin konut sorununa nasıl çözüm arandı? [How was the housing question of Turkey tried to be solved in seventy years?] In Konut Araştırmaları Sempozyumu, Toplu Konut İdaresi Başkanlığı (pp. 1-10), Ankara.

TOKI (2011a). Building Turkey of the future: corporate profile 2010/2011. Ankara: TOKI

TOKI (2011b). Illere Göre TOKI Uygulamaları [TOKI projects by provinces]. <http:// www.toki.gov.tr> Accessed 25.07.11.

Tuğal, C. (2006). The appeal of islamic politics: Ritual and dialogue in a poor district of Turkey. The Sociological Quarterly, 47, 245-273.

Türel, A. (1994). Gecekondu Yapım Süreci ve Dönüşümü [The process of gecekondu construction and its transformation]. In Kent, Planlama, Politika, Sanat: Tarık Okyay Anısına Yazılar, I Tekeli (ed.), METU Faculty of Architecture, Ankara, pp. 637-650.

Vale, L. J. (1992). Architecture, power, and national identity. New York: Routledge.

White, J. (2003). Islamist mobilization in Turkey: a study in vernacular politics. Seattle and London: University of Washington Press.

Yıldız, D. (2009). "Ankara”, "Su" ve "Gelecek"! [Ankara, water and the future]. Dosya, 11, 71-79. 